\title{
"SISTEM PENGENDALIAN MANAJEMEN TERHADAP KINERJA KARYAWAN \\ DI WARUNG SATE KAMBING DAN GULE MORO LEGO PAK KUWAT \\ KABUPATEN TULUNGAGUNG"
}

Yedida Cahya Arisma Putri, Fadilatul jannah, Putri Intan Permata Sari

ayanggchy9@gmail.com / fadilatuljannah8@gmail.com / putriintanps1234@gmail.com

\begin{abstract}
Abstrak
Penelitian ini bertujuan untuk menjelaskan hasil analisis dari sistem pengendalian manajemen dan pengaruhnya kinerja karyawan di warung sate kambing dan gule "MORO LEGO" kabupaten Tulungagung. Sistem pengendalian manajemen ini merupakan salah satu alat organisasi yang penting untuk menunjang kinerja yang optimal dari suatu perusahaan.untuk menentukan keberhasilan serta pengembangan perusahaan yang berkelanjutan, maka perusahaan saat ini harus memiliki sitem yang baik dan tenaga kerja yang berkualitas, sistem yang baik salah satunya adalah sistem pengendalian manajemen yang optimal. Sistem pengendalian manajemen merupan sistem yang digunakan oleh manajer untuk mempengaruhi karyawan atau anggota perusahaan agar melaksanakan strategi dan kebijakan organisasi secara efektif dan efesien dalam rangka mencapai tujuan organisasi. Sistem pengendalian manjemen ini merupakan alat yang digunakan oleh pihak manajemen untuk meningkatkan kinerja perusahaan dalam kinerja manajerial. Penelitian ini menggunakan metode pendekatan kualitatif dengan menggunakan wawancara, observasi, dan analisi dokumen sebagai metode untuk mendapatkan data. Hasil dari penelitian yang dilakukan, dimaksudkan untuk menjelaskan bahwa sistem pengendalian manajemen yang diperlukan oleh warung kuliner ini untuk meningkatkan kinerja karyawan sehingga dapat terbentuk suasana kerja yang kondusif antara atasan dan karayawan, serta membentuk ras kekeluargaan dan kerjasama pada masing-masing karyawan.
\end{abstract}

\section{Kata kunci: kinerja manajemen, sistem pengendalian manajemen}

\begin{abstract}
This study aims to explain the results of the analysis of the management control system and its effect on the performance of employees at the sate goat and gule moro lego stalls in Tulungagung district. This management control system is one of the important organizational tools to support the optimal performance of a company. To determine the success and sustainable development of the company, the current company must have a good system and a quality workforce, a good system one of which is optimal management control system. Management control system is a system used by managers to influence employees or company members to implement organizational strategies and policies effectively and efficiently in order to achieve organizational goals. This management control system is a tool used by the management to improve the company's performance in managerial performance. This study uses qualitative approach methods using interviews, observations, and document analysis as methods for obtaining data. The results of the research conducted, intended to explain that the management control system needed by this culinary stall to improve employee performance so that a conducive work atmosphere can be formed between superiors and friends, as well as forming family races and cooperation in each employee.
\end{abstract}

Keywords: management performance, management control system 


\section{PENDAHULUAN}

\section{Latar Belakang}

Terdapat beberapa alasan mengapa sistem pengendalian manajemen menjadi sangat penting bagi suatu karyawan karena untuk perumusan dan pengimplementasian strategi. Sistem pengendalian manajemen sangat penting untuk keunggulan bersaing dan keunggulan kinerja bagi karyawan, dengan sendirinya dijadikan sebagai alat untuk memudahkan karyawan dalam menggunakan semua sumberdaya baik yang bersifat nyata maupun tidak nyata untuk bersaing. Oleh karena itu semua karyawan berusaha agar orientasi kinerja dan strategi bisnis dapat direfleksikan dalam sistem pengendalian manajemen yang merupakan fungsi kritis dalam organisasi. Tujuan jangka pendek setiap perusahaan adalah mencapai tingkatan profit yang memuaskan, sedangkan tujuan jangka panjang lebih mengarah pada keeksistenan perusahaan itu sendiri Untuk mencapai tujuan-tujuan yang sudah direncanakan maka perusahaan harus memiliki suatu sistem pengendalian manajemen yang baik(Mahdini, 2019). Hal ini dilakukan oleh perusahaan untuk mempermudah perusahaan melakukan penilaian kinerja para pegawainya. Karena dengan penilaian kinerja perusahaan dapat mengetahui hal-hal apa saja yang harus lebih diperhatikan perusahaan mengenai para pegawainya karena pegawai merupakan ujung tombak sebuah perusahaan yang peranannya sangat penting untuk pencapaian tujuan perusahaan.

Di samping itu dengan penilaian kinerja dapat menyadarkan dan meyakinkan pegawai mengenai pentingnya tindakan perbaikan atas pekerjaan-pekerjaan yang telah dilakukan. Karena tidak sedikit pegawai yang memiliki tujuan yang berbeda dengan tujuan perusahaan. Efektifitas kinerja sebuah divisi merupakan cerminan dari efektifitas kinerja manajer yang memimpinnya. Seperti halnya para karyawan, para manajer pun tentu saja dinilai kinerjanya. Penilaian kinerja para manajer dari tiap-tiap divisi ini dilakukan oleh manajer pusat yang bertugas dikantor pusat. Setiap manajer divisi harus melaporkan kegiatan operasional divisi yang dipimpinnya tersebut kepada manajer pusat. Manajer pusat ini bertugas sebagai controller (pengendali). Jika seorang manajer divisi atau unit bisnis melakukan pengendalian manajemen terhadap para pegawai dalam divisinya, maka seorang manajer pusat melakukan pengendalian manajemen pada seluruh divisi yang ada dalam sebuah perusahaan tersebut. Pengendalian manajemen ini sangat penting dilakukan untuk menciptakan keselarasan antar divisi dalam perusahaan yang dipimpin oleh para manajer yang berbeda. 
Perusahaan yang didalamnya terdapat pengendalian manajemen yang baik akan lebih mudah mencapai tujuan baik tujuan jangka pendek ataupun jangka panjang dibandingkan dengan perusahaan yang tidak memiliki pengendalian manajemen yang memadai. Karena pengendalian manajemen merupakan hal yang sangat penting, biasanya pengendalian manajemen ini dilakukan dengan sebuah sistem agar pelaksanaannya dapat berjalan.

Sistem pengendalian manajemen (SPM) merupakan suatu hal yang sangat penting dalam pengendalian formal dan sistem umpan balik atau Feedback yang dimaksudkan untuk memonitor suatu hasil organisasi dan mengkoreksi penyimpangan standart dari kinerja yang ditetapkan sebelumnya. Pengendalian manajemen telah menjadi salah satu area penting dalam penelitian perilaku organisasi, yang sejalan dengan pertumbuhan tekanan ekonomi, iklim industri yang tidak menentu, krisis ekonomi, dan keadaan lingkungan eksternal lainnya seperti konsumen, tingkat persaingan, pasar, pemasok, distributor, serta sikap masyarakat dan pemerintahan.

Pada warung kuliner sate kambing dan gule "MORO LEGO" Pak Kuwat ini semua sangat mempunyai pengaruh yang penting dalam melayani para konsumennya. Hal tersebut merupakan suatu tantangan bagi seorang manajer, dimana sebagai pihak yang langsung berhubungan dengan para pegawai untuk menciptakan struktur karyawan yang handal, agar kepercayaan dan kepuasan konsumen dapat tercapai. Seorang manajer harus memiliki kemampuan untuk memotivasi dan mempengaruhi para bawahannya dengan pengaruh yang positif, sehingga para pegawai sudah memiliki kesadaran untuk memberikan pelayanan yang terbaik.

Penelitian ini dilakukan untuk mengetahui pengaruh sistem pengendalian manajemen terhadap kinerja karyawan pada warung sate kambing dan gule "MORO LEGO" Pak Kuwat Kabupaten Tulungagung, mengetahui bagaimana kinerja karyawan pada warung sate kambing dan gule "MORO LEGO” Pak Kuwat Kabupaten Tulungagung. Serta diharapkan ke depannya mampu menjadi salah satu referensi mengenai pengaruh penerapan sistem pengendalian manajemen terhadap kinerja karyawan warung sate kambing dan gule "MORO LEGO” Pak Kuwat Kabupaten Tulungagung. 


\section{KAJIAN TEORI}

Organisasi yang merupakan suatu unit social yang dibentuk untuk mencapai tujuan tertentu, sistem pengendalian manajemen yang sangat diperlukan oleh manajemen untuk membantu memperlancar pencapaian tujuan organisasi tersebut. (Anthony\&Govindharajan, 1995) sistem pengendalian organisasi yang juga bisa disebut sebagai sistem pengendalian administratif dan birokratis, sengaja di desain untuk mengarahkan atau mengatur semua aktivitas anggota organisasi agar sesuai dengan yang dikehendaki oleh seorang pimpinan organisasi. Akan tetapi keefektifan suatu sistem pengendalian ditentukan antara lain oleh seberapa jauh sistem tersebut sesuai dengan karakteristik organisasi.

Hofstede, Neuijen \& Sanders (1990) menemukan bahwa sistem pengendalian yang berbeda untuk organisasi yang berbeda terutama bila ditinjau dari kultur organisasional (budaya perusahaan) menunjukkan bahwa perbedaan tersebut dipengaruhi oleh factor-faktor organisasional, sistem pengendalian dan profil karyawan. Budaya perusahaan yang secara dominan mempunyai pengaruh kuat terhadap anggota organisasi, dengan demikian berarti budaya akan mendukung keberhasilan manajemen dalam mengimplementasi strategi perusahaan karena budaya perusahaan yang mengarahkan seluruh perilaku anggota organisasi dalam mencapai sasaran perusahaan dengan cara meningkatkan koordinasi dan pengendalian dalam perusahaan (Hofstede et. All., 1990; Indriantoro, 2000).

Harrison dan Mc Kinnon (1999) menalaah kembali sebuah riset-riset lintas budaya akan sistem pengendalian manajemen bahwa riset lintas budaya ini tidak menggunakan dimensi budaya menurut hasil kerja, yang secara lengkap masih memandang hanya kepada satu atau dua sub sistem atau bagian dari sistem pengendalian manajemen. Yang hanya menganggap bahwa riset budaya dalam sistem pengendalian manajemen masih belum matang sehingga banyak peluang yang bisa dilakukan untuk riset mendatang, dengan sebaiknya lebih mencoba menggunakan metode metode dari ilmu social lainnya.

\section{Pengertian Sistem Pengendalian Manajemen}

Sistem pengendalian manajemen pada dasarnya merupakan suatu sistem yang dipergunakan manajemen dalam membangun masa depan organisasi. Sistem pengendalian manajemen merupakan suatu sistem yang digunakan oleh para manajer untuk mengarahkan para anggota organisasi agar melaksanakan kegiatan organisasi secara efektif dan efisien sesuai strategi pokok yang telah ditentukan untuk mencapai tujuan yang telah ditetapkan. Sistem pengendalian manajemen berlandaskan kepada strategi bisnis(Skripsi tesis, 2018)(W et al., 2018). 
Strategi bisnis yang baik akan meningkatkan sistem pengendalian manajemen yang pada akhirnya mendatangkan keberhasilan pada suatu organisasi. Sistem perencanaan atau pengendalian manajemen adalah suatu sistem yang digunakan untuk merencanakan sasaran masa depan yang hendak dicapai oleh organisasi, merencanakan kegiatan untuk mencapai sasaran tersebut, serta mampu mengimplementasikan dan memantau rencana yang telah ditetapkan.

\section{Tujuan pengendalian internal terbagi menjadi dua, yaitu :}

1. Menjaga kekayaan perusahaan.

2. Pertanggung jawaban kekayaan perusahaan yang dicatat akan dibandingkan dengan kekayaan yang sesungguhnya.

Menurut Suadi (1999:8-9) Sistem pengendalian manajemen adalah: sebuah sistem yang terdiri dari beberapa sub sistem yang saling berkaitan, yaitu: pemrograman, penganggaran, akuntansi, pelaporan, dan pertanggungjawaban untuk membantu manajemen mempengaruhi orang lain dalam sebuah perusahaan, agar mau mencapai tujuan perusahaan melalui strategi tertentu secara efektif dan efisien(Skripsi tesis, 2018).

\section{Pengertian Kinerja}

Kinerja berasal dari kata Job Performance atau actual performance yang berarti prestasi kerja atau prestasi sesungguhnya yang dicapai oleh seseorang. Menurut Anwar Prabu Mangkunegara Kinerja merupakan hasil kerja secara kuantitas dan kualitas yang dicapai seorang pegawai dalam melaksanakan tugas dan sesuai dengan tanggung jawab yang diberikan. Hubeis Dan Mangkuprawira (007:153) juga mengungkapkan, Kinerja merupakan hasil dari pekerjaan tertentu secara berencana pada waktu dan tempat dari karyawan serta organisasi bersangkutan(Materi, 2021). Pengertian kinerja adalah hasil kerja secara kualitas dan kuantitas yang dicapai oleh seorang pegawai dalam melaksanakan fungsinya sesuai dengan tanggung jawab yang diberikan kepadanya. 


\section{Pengertian Karyawan}

Menurut Undang-undang nomor 13 tahun 2003 tentang ketenaga kerjaan pasal 1 ayat 2 menyebutkan bahwa karyawan adalah setiap orang yang mampu melakukan pekerjaan guna menghasilkan barang dan jasa baik untuk memenuhi kebetuhan sendiri maupun masyarakat, baik didalam maupun diluar hubungan kerja. Hasibuan "Dalam Manulang, 2002" mengungkapkan, Karyawan merupakan orang penjual jasa "pikiran atau tenaga" dan mendapat kompensasi yang besarnya telah ditetapkan telebih dahulu. Anwar Prabu

\section{Mangkunegara}

Kinerja juga memiliki indikator tersendiri dalam penilainnya seperti yang diungkapa Anwar Prabu Mangkunegara yakni diantaranya ialah kualitas dan kuantitas, pelaksanaan tugas dan tanggung jawab yang bisa dijabarkan sebagai berikut:

a. Kualitas-kualitas disini ialah bagaimana seorang pegawai atau karyawan dalam menjalankan tugasnya apakah baik atau tidak.

b. Kuantitas-kuantitas ialah waktu yang dihabiskan oleh pegawai dalam menjalankan tugasnya dalam satu hari dan bisa diukur berdasarkan kecepatan kerja dari pergawai tersebut.

c. Tanggung jawab, dalam hal ini merupakan kesadaran pegawai akan tanggung jawabnya dalam melaksanakan tugas yang sudah diberikan oleh perusahaan.

d. Pelaksanaan tugas merupakan kemampuan pegawai atau karyawan untuk melakukan tugasnya apakah dikerjakan dengan akurat tanpa melakukan kesalahan atau tidak. Kinerja karyawan ini dipengaruhi oleh beberapa faktor seperti faktor kemampuan dan faktor motivasi. 


\section{ANALISIS DATA DAN PEMBAHASAN}

Sistem pengendalian manajemen merupakan suatu sistem yang terintegrasi antara proses, strategi, pemrograman, menganggaran, akuntansi, dan akuntabilitas yang pada dasarnya digunakan untuk membantu dalam mengelola suatu perusahaan serta mencapai hal yang terbaik. Dalam sistem pengendalian manajemen, faktor psikologis akan lebih mendominasi. Sebab tugas terpenting dalam manajemen melalui sistem pengendalian ini adalah mengupayakan tercapainya tujuan organisasi secara efektif dan efisien.

Sistem pengendalian manajemen memiliki beberapa ciri yang utama sebagai berikut :

1. Sistem pengendalian manajemen yang digunakan untuk mengendalikan seluruh organisasi, termasuk pengendalian sumber daya yang digunakan serta hasil yang diperoleh organisasi sehingga proses pencapaian tujuan organisasi dapat berjalan lancar dan semestinya.

2. Pengendalian manajemen dimulai dengan strategi dan teknik evaluasi yang komperhensif, serta akurasinya bersifat kurang pasti saat sedang mengevaluasi sesuatu.

3. Pengendalian manajemen lebih berorientasi kepada manusia, karena pengendalian manajemen lebih ditujukan untuk membantu tugas manajer dalam menerapkan strategi organisasi.

Beberapa tujuan perancangan sistem pengendalian manajemen, antara lain adalah :

1. Keandalan dan kelengkapan informasi yang diperoleh.

2. Mematuhi kebijakan, rencana, prosedur, aturan dan ketentuan yang berlaku.

3. Melindungi aset perusahaan.

4. Mewujudkan kegiatan yang hemat biaya.

Sistem pengendalian manajemen yang dapat diandalkan (reliable) memiliki unsur-unsur yang harus dipenuhi, yaitu :

1. Keterampilan karyawan yang sepadan dengan tugasnya.

2. Pemisahan tugas.

3. Sistem pemberian wewenang, tujuan, dan teknik, serta pengawasan yang tepat dalam mengadakan pengendalian harga, hutang, penerimaan, dan pengeluaran.

4. Pemeriksaan fisik aset dengan catatan aset dan kewajiban. 


\section{A. Gambaran Umum Warung Sate Kambing dan Gule "MORO LEGO"}

Tulungagung merupakan daerah Jawa timur yang menawarkan wisata kuliner nikmat dan beragam. Aneka macam kuliner berjajar di sekitar kawasan stasiun Tulungagung tepatnya di kelurahan Kampungdalem, Kecamatan Tulungagung Kabupaten Tulungagung. Mulai dari oleh-oleh khas Tulungagung, jajanan, olahan unggas, dan yang popular aadalah sate kambing. Salah satunya adalah warung kuliner Sate kambing dan gule "MORO LEGO" Pak Kuwat. Warung kuliner ini berlokasi di dua tempat. Pertama, berlokasi di Jl. M Husni Thamrin. Selanjutnya, cabang lain ada di Jl. Teuku Umar No. 1. Bisa dipilih dimana lokasi yang paling dekat dengan keberadaan konsumen. Warung kuliner sate kambing dan gule “MORO LEGO” buka mulai pagi pkl 07.00 sampai malam pkl 21.00 WIB.

Sate Pak Kuwat ini memiliki ciri khas bumbu kecap yang kuat tentunya berbeda dengan lazimnya sate yang menggunakan bumbu kacang. Bumbu kecap dengan campuran rempah ini memang khas di Tulungagung, ditambah dengan sedikit irisan bawang merah dan cabai. Sudah banyak pelancong-pelancong yang berkunjung ke Tulungagung dan sengaja mampir ke warung kuliner Sate Kambing dan gule Pak Kuwat ini. Warung yang berdiri sejak tahun 1992 ini berlokasi di dekat stasiun Tulungagung tepatnya berada di pojok, sebelah kiri pintu masuk stasiun Tulungagung. Bukan hanya sate yang disajikan di warung ini, ada juga sup iga kambing, kambing oven, hot plate iga, gule, krengsengan kambing, dan hidangan lainnya.

\section{B. Teknik Pengumpulan Data}

Teknik dan pengumpulan data yang digunakan adalah kuesioner atau metode angket dengan menggunakan daftar pertanyaan yang disampaikan secara langsung kepada responden. Metode kuesioner yaitu dengan cara melakukan pengumpulan data yang disajikan dalam bentuk pertanyaan-pertanyaan kepada responden, terkait dengan pelayanan yang diterima sehingga responden dapat memberikan jawaban atas pertanyaan secara tertulis.

Teknik pengumpulan data dalam penelitian ini adalah observasi yaitu yang merupakan suatu aktivitas terhadap suatu proses atau objek yang dimaksud dengan merasakan kemudian memahami pengetahuan dari sebuah fenomena berdasarkan pengetahuan dan gagasan yang sudah diketahui, untuk mendapatkan sebuah informasi yang dibutuhkan dalam suatu penelitian. Observasi dalam penelitian ini melihat kondisi atau keadaan secara langsung tempat penelitian yaitu warung sate kambing dan gule "MORO LEGO” Pak Kuwat Tulungagung. 
Instrumen untuk mengukur sistem pengendalian manajemen dan kinerja karyawan adalah sebagai berikut :

\begin{tabular}{|c|c|c|}
\hline No. & Variabel & Indikator \\
\hline 1. & Pengendalian manajemen & $\begin{array}{l}\text { 1. Lingkungan pengendalian. } \\
\text { 2. Penilaian resiko. } \\
\text { 3. Aktivitas pengendalian. } \\
\text { 4. Komunikasi dan Informasi. } \\
\text { 5. Aktivitas pengawasan. }\end{array}$ \\
\hline 2. & Kinerja karyawan & $\begin{array}{l}\text { 1. Kuantitas hasil kerja. } \\
\text { 2. Kualitas hasil kerja. } \\
\text { 3. Ketepatan waktu. } \\
\text { 4. Pekerjaan. }\end{array}$ \\
\hline
\end{tabular}

Setiap sistem pengendalian manajemen memiliki setidaknya 4 elemen, yaitu :

\section{Pelacak (Detector)}

Yang merupakan suatu perangkat untuk mengukur suatu hal yang sesunguhnya terjadi dalam proses yang sedang dikendalikan.

\section{Penilai (Assesor)}

Suatu perangkat untuk menentukan signifikasi dari peristiwa aktual dengan membandingkan peristiwa aktual dengan standart atau harapan tertentu tentang apa yang seharusnya terjadi.

\section{Effector}

Suatu perangkat atau umpan balik yang mengubah perilaku jika assesor menunjukkan bahwa perilaku tersebut perlu diubah.

\section{Jaringan Komunikasi}

Perangkat yang meneruskan informasi antara detector, assessor, dan efector. (W et al., 2018) 


\section{Proses sistem manajemen :}

\section{Pemrograman}

Tahap ini perusahaan akan menentukan program yang akan dijalankan dan memperkirakan sumber daya yang akan dialokasikan pada setiap program yang telah ditentukan.

\section{Penganggaran}

Tahap ini program yang direncanakan secara rinci dalam jangka waktu tertentu yang akan dinyatakan dalam satuan mata uang.

\section{Operasi dan akuntansi}

Tahap ini akan dilaksanakan pencatatan mengenai berbagai sumber daya yang digunakan dan penerimaan yang dihasilkan.

\section{Pelaporan dan analisis}

Tahap ini merupakan yang paling penting karena menutup suatu siklus dari pengendalian manajemen agar data untuk proses tersebut dapat dipertanggungjawabkan serta dapat dikumpulkan.

Beberapa nilai utama yang harus dijunjung tinggi oleh semua staf baik manager dan karyawan, adalah sebagai berikut :

\section{a. Integritas}

$\rightarrow$ Bertindak sesuai dengan nilai-nilai kebijakan organisasi dan kode etik suatu perusahaan. Memiliki pemahaman dan keinginan untuk menyesuaikan diri dengan kebijakan dan etika tersebut, serta bertindak secara konsisten.

\section{b. Profesional}

$\rightarrow$ Dimana seseorang memiliki kemampuan dan penguasaan dalam bidang pengetahuan yang terkait dengan pekerjaannya, serta mampu menguasai untuk menggunakan, mengembangkan, dan membagikan pengetahuan kepada yang lain.

\section{c. Keselamatan}

$\rightarrow$ Memiliki sifat tanpa kompromi dan secara konsisten dalam menjalankan tugasnya atau menciptakan sistem atau proses kerja yang mempunyai potensi risiko yang rendah terhadap terjadinya kecelakaan dan menjaga aset perusahaan dari kemungkinan terjadi kerugian.

\section{d. Inovasi}

$\rightarrow$ Dimana harus selalu menumbuh kembangkan gagasan baru, dan melakukan tindakan perbaikan yang berkelanjutan serta mampun menciptakan lingkungan kondusif untuk berkreasi sehingga memberikan nilai tambah bagi Stakeholder. 


\section{Logo Perusahaan dan Visi Misi Perusahaan}
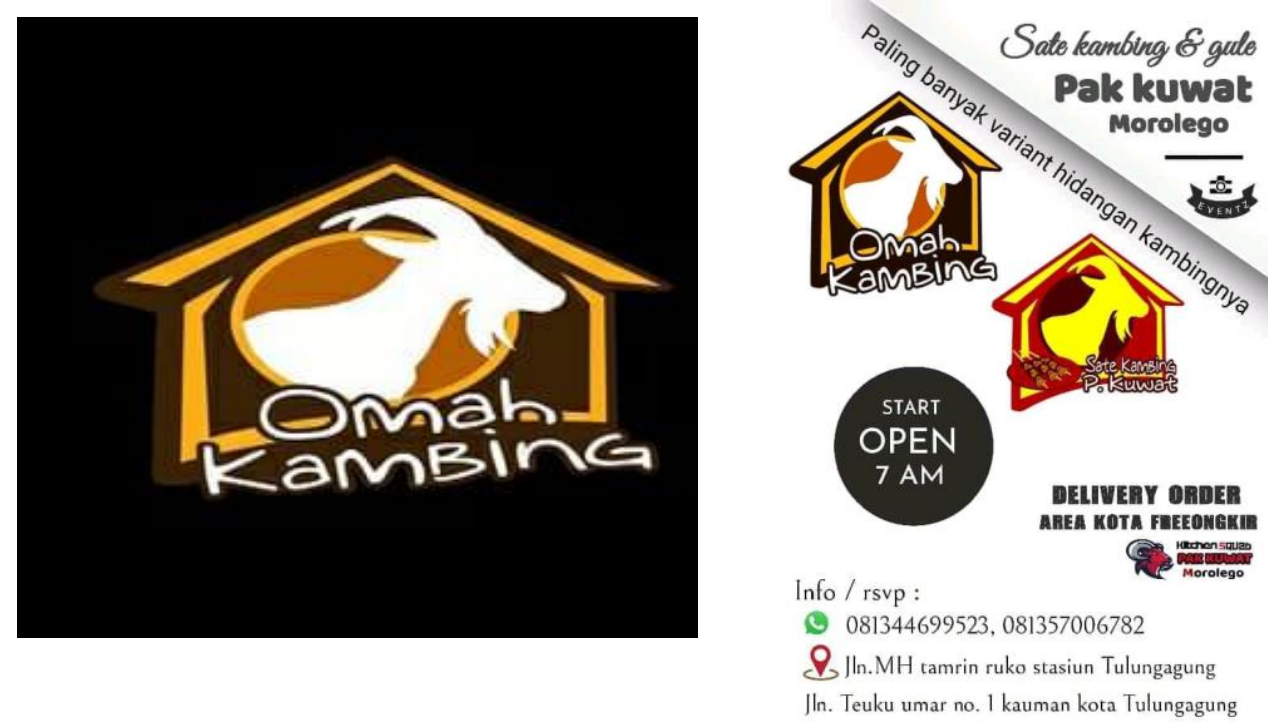

Logo merupakan suatu identitas visual terhadap suatu entitas yang mempunyai kriteria khusus seperti bentuk, filosofi, dan warna(Kompas.com, 2021). Pada dasarnya kata logo itu sendiri yang diserap dari bahasa Yunani kuno, yakni Logos yang mempunyai arti pikiran, budi, kata, akal, serta pembicaraan. Suatu logo mengandung filosofi tertentu dan kerangka dasar berbentuk konsep yang bertujuan guna menciptakan sifat mandiri. Selain itu, setiap bentuk logo juga wajib mempunyai suatu ciri khas tertentu untuk membedakan logo yang satu dengan logo yang lain. Suatu logo yang digunakan akan menggambarkan kualitas seperti yang disimbolkan, seperti adanya pendekatan budaya perusahaan, penempatan posisi penting, atau aspirasi dari perusahaan itu sendiri. Atau suatu instrumen yang menggambarkan harga diri dimana seluruh nilainya mampu mewujudkan citra yang baik dan dapat dipercaya.

Seperti halnya seperti logo dari warung sate kambing dan gule "MORO LEGO" Pak Kuwat Kabupaten Tulungagung, yang menjadi suatu identitas kurang lebih 15 tahun. Logo ini diberi tema "Omah Kambing" yang bermakna rumah aneka olahan daging kambing. Menjadi suatu ciri khas bagi masyarakat, serta menghasilkan suatu kualitas dan integritas yang harus dimiliki dan juga mampu memberikan sinergi atau inovasi pada semua bidang sehingga nama "Omah Kambing" ini dapat berkembang pesat di kalangan struktur masyarakat. 


\section{PENUTUP}

\section{Kesimpulan}

Pengendalian manajemen adalah proses dimana seorang manajer mempengaruhi anggotanya untuk melaksanakan strategi organisasi. Sistem pengendalian manajemen merupakan perangkat struktur komunikasi yang saling berhubungan serta memudahkan pemrosessan informasi dengan maksud membantu manajer mengkoordinasikan bagianbagian yang ada dan pencapaian tujuan organisasi secara terus-menerus. Pada dasarnya sistem ini berisi tuntutan kepada kita mengenai cara menjalankan dan mengendalikan perusahaan atau organisasi yang dianggap baik berdasarkan asumsi-asumsi tertentu. masingmasing perusahaan memiliki kompleksitas berbeda dalam pengendalian manajemen, semakin besar skala perusahaan maka akan semakin kompleks. Tujuan dari sistem ini adalah untuk meningatkan keputusan-keputusan kolektif dalam berorganisasi. Untuk memahami sebuah sistem dibutuhkan suatu pengetahuan tentang lingkungan dimana sistem itu berada.

\section{Saran}

Suatu perusahaan perlu adanya pengendalian manajemen agar suatu upaya sistematis yang akan dilakukan perusahaan untuk mencapai tujuannya dapat dilakukan dengan cara melakukan perbandingan atas prestasi kerja agar sesuai rencana awal dan menciptakan suatu tindakan yang tepat utuk bisa mengoreksi setiap perbedaan yang menyimpang. Perusahaan juga perlu meningkatkan pengendaliannya untuk mencapai tujuan yang ditetapkan oleh perusahaan. sehingga peran manjer sangat penting dalam perusahaan, maka dari itu seorang manajer perlu meningkatan kemampuannya dalam mengelola asset perushaan yang berpengaruh untuk kelangsungan hidup suatu perusahaan. 


\section{DAFTAR PUSTAKA}

Kompas.com. (2021). Fungsi Logo, Jenis, dan Aspeknya. Kompas.Com.

https://www.kompas.com/skola/read/2021/11/25/170000869/fungsi-logo-jenis-dan-aspeknya

Mahdini, R. I. (2019). Pengaruh penerapan sistem pengendalian manajemen terhadap kinerja karyawan pada pt. kereta api sumatera utara skripsi.

Materi, A. (2021). Pengertian Kinerja Menururt Para Ahli - Faktor, Karateristik Dan Indikator. Materi Belajar.Co.Id. https://materibelajar.co.id/pengertian-kinerja-menururt-para-ahli/

Skripsi tesis. (2018). Pembahasan Lengkap Teori Sistem Pengendalian Manajemen menurut Para Ahli dan Contoh Tesis Sistem Pengendalian Manajemen. Idtesis.Com.

https://idtesis.com/pembahasan-lengkap-teori-sistem-pengendalian-manajemen-menurutpara-ahli-dan-contoh-tesis-sistem-pengendalian-manajemen/

W, R. S., S, E. D., Prasetya, B., A, R. W., Prasetya, I., \& Pratiwi, K. (2018). HAKIKAT SISTEM PENGENDALIAN MANAJEMEN\&MEMAHAMI STRATEGI.

https://www.academia.edu/34706824/MAKALAH_SISTEM_PENGENDALIAN_MANAJEMEN 
